\title{
RAG2 Gene
}

National Cancer Institute

\section{Source}

National Cancer Institute. RAG2 Gene. NCI Thesaurus. Code C80069.

This gene plays a role in immunog lobulin diversity. 